Primljen / Received: 20.9.2020

Ispravljen / Corrected: 8.11.2020

Prihvaćen / Accepted: 25.11.2020.

Dostupno online / Available online: 10.3.2021

\section{Methods for determining mechanical properties of walls}

Authors:

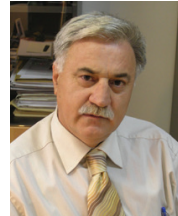

'Joško Krolo, PhD. CE krolo@grad.hr

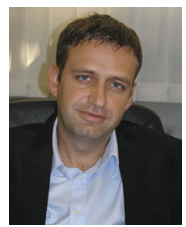

${ }^{1}$ Assoc.Prof. Domagoj Damjanović domagoj.damjanovic@grad.unizg.hr Corresponding author

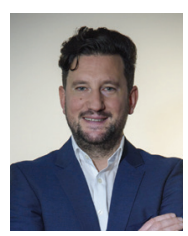

'Assist.Prof. Ivan Duvnjaki iduvnjak@grad.hr

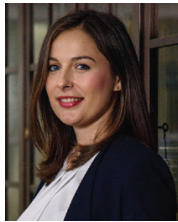

'Marina Frančić Smrkić, PhD. CE marina.francic.smrkic@grad.unizg.hr

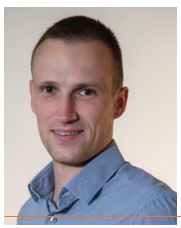

${ }^{1}$ Assist.Prof. Marko Bartolac marko.bartolac@grad.unizg.hr

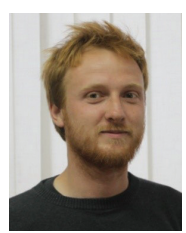

${ }^{1} J a n k o$ Košćak, MCE

jkoscak@grad.hr

${ }^{1}$ University of Zagreb

Faculty of Civil Engineering

Department of Engineering Mechanics
Joško Krolo, Domagoj Damjanović, Ivan Duvnjak, Marina Frančić Smrkić, Marko Bartolac, Janko Košćak

\section{Methods for determining mechanical properties of walls}

Masonry buildings with wooden floor structures, not equipped with vertical and horizontal tie beams, suffered the greatest damage in the earthquake that hit Zagreb on 22 March 2020. It is very significant to know mechanical properties of walls during preparation of the masonry buildings renovation design and, consequently, methods for determining such properties are presented in detailed in this paper. In addition to description of these methods, results obtained by testing shear strength of walls of twenty masonry buildings in Zagreb (149 measuring points in total) are also presented, as well as the results obtained by testing compressive strength of bricks on 14 buildings, using a total of 62 samples.

Key words:

walls, mechanical properties, testing, shear strength, compressive strength

Pregledni rad

Joško Krolo, Domagoj Damjanović, Ivan Duvnjak, Marina Frančić Smrkić, Marko Bartolac, Janko Košćak

\section{Metode odredivanja mehaničkih svojstava zida}

U potresu koji je 22. ožujka 2020. pogodio Zagreb najteže su stradale zidane zgrade s drvenim međukatnim konstrukcijama koje nemaju vertikalne i horizontalne serklaže. Za izradu projekta obnove zidanih zgrada vrlo je važno poznavanje mehaničkih svojstava ziđa te su u ovom radu detaljno opisane metode za njihovo određivanje. Osim opisa metoda, prikazani su i rezultati ispitivanja posmične čvrstoće ziđa koji su provedeni na 20 zidanih građevina na području Zagreba (ukupno 149 mjernih mjesta) te rezultati ispitivanja tlačne čvrstoće opeke za 14 zgrada (ukupno 62 ispitana uzorka).

Ključne riječi:

zide, mehanička svojstva, ispitivanje, posmična čvrstoća, tlačna čvrstoća

Übersichtsarbeit Joško Krolo, Domagoj Damjanović, Ivan Duvnjak, Marina Frančić Smrkić, Marko Bartolac, Janko Košćak

Methoden zur Bestimmung der mechanischen Eigenschaften des Mauerwerks

Bei dem Erdbeben in Zagreb am 22. März 2020 wurden Mauerwerksgebäude mit Holzkonstruktionen zwischen den Etagen ohne vertikale und horizontale Ringanker am stärksten beschädigt. Die Kenntnis der mechanischen Eigenschaften von Mauerwerk ist für die Vorbereitung eines Projekts zur Renovierung von Mauerwerksgebäuden von großer Bedeutung. In dieser Arbeit werden die Methoden zu ihrer Bestimmung ausführlich beschrieben. Neben der Beschreibung der Methoden wurden die Ergebnisse der Prüfung der Scherfestigkeit von Mauerwerk an 20 Mauerwerksgebäuden im Raum Zagreb (insgesamt 149 Messpunkte) sowie die Ergebnisse der Prüfung der Druckfestigkeit von Ziegeln bei 14 Gebäuden (insgesamt 62 geprüfte Proben) vorgestellt.

Schlüsselwörter:

Mauerwerk, mechanische Eigenschaften, Prüfung, Scherfestigkeit, Druckfestigkeit 


\section{Introduction}

Many masonry buildings suffered heavy damage in the earthquake that struck Zagreb on 22 March 2020. This especially concerns the buildings built in the early twentieth century, with walls made of solid brick and lime mortar. The retrofitting and structural strengthening of these buildings is a highly demanding procedure normally carried out over a longer period. The structural system of most of these buildings was weakened even before the earthquake [1]. This is mainly due to the systematic lack of maintenance, previous damage (such as damage from prior earthquakes of lower intensity), and uncontrolled interventions aimed at changing occupancy (demolishing walls to make new openings or closing the existing ones, space partitioning, etc.). In addition, these buildings do not meet various modern requirements regarding the load-bearing capacity and serviceability, nor do they comply with requirements for seismic resistance of buildings as specified in Eurocode 6 [2] and Eurocode 8 [3].

In order to obtain valid input data for the retrofit design of the damaged buildings, previous research and testing aimed at determination of actual masonry mechanical properties is highly recommended. The methods for testing of mechanical properties of solid brick walls are presented in this paper, and the corresponding test results are provided. According to the relevant standard requirements [4], destructive and non-destructive tests can be used to test materials incorporated in masonry structures.

The standard makes the distinction between:

- limited in situ testing,

- extended in situ testing, and

- comprehensive in situ testing.

The inspection and testing level is defined depending on the percentage of structural elements to be controlled in detail and on the number of material specimens to be taken for testing per each floor. Minimum values for the usual situations are indicated in Table 1 :
When defining properties of existing materials to be used in the capacity analysis, i.e. when comparing their capacity with the requirements during safety verifications, average values obtained by in situ testing and those gained from additional sources, must be divided with the factor of confidence (CF) given in Table 2 for the corresponding level of knowledge.

The data from Tables 1 and 2, indicated as recommended values in the Croatian national annex to the standard HRN EN 1998-3/NA, have been accepted without modification and have thus become obligatory. The standard Eurocode 8: Design of structures for earthquake resistance - Part 3: Assessment and retrofitting of buildings [4] does not specify the type of testing, nor the specimen type to be taken, in the case of masonry buildings. Tests that can be implemented for masonry buildings involve testing compressive, shear, and tensile strength of masonry walls, and modulus of elasticity, as well as taking brick samples and testing their compressive strength.

Therefore, to use confidence factor for the knowledge level 3 $\mathrm{CF}_{\mathrm{KL} 3}=1.0$ in the design of masonry structures, it is necessary to cover by inspection at least $80 \%$ of the elements and test masonry walls at no less than 3 points per each floor of the building.

\section{In situ masonry shear strength}

This testing is conducted using a small hydraulic jack by which a minimum damage is induced on the structure of an existing loadbearing wall. This type of test enables a relatively fast check of the masonry shear strength at several locations. In many cases, the buildings concerned are of notable historical significance (protected cultural heritage, or buildings located within a protected cultural-historic zone). Therefore, it is often requested that the works in the scope of this test are to be carried out by generating minimum damage to the existing structure.

Table 1. Recommended minimum requirements for various inspection and testing levels [4]

\begin{tabular}{|c|c|c|}
\hline \multirow[t]{2}{*}{ Inspection level } & Inspection (of details) & Testing (of materials) \\
\hline & \multicolumn{2}{|c|}{ For each type of primary elements (beam, column, wall) } \\
\hline Inspection and testing level & Percentage of elements that are checked for details & Material specimens per floor \\
\hline Limited in situ testing & $20 \%$ & 1 \\
\hline Extended in situ testing & $50 \%$ & 2 \\
\hline Comprehensive in situ testing & $80 \%$ & 3 \\
\hline
\end{tabular}

Table 2. Recommended confidence factors [4]

\begin{tabular}{|c|l|c|c|}
\hline \multicolumn{2}{|c|}{ Knowledge level } & \multicolumn{2}{|c|}{ Recommended factor of confidence values } \\
\hline $\mathbf{K L 1}$ & $\begin{array}{l}\text { Limited knowledge - Default values in accordance with standards of the time of } \\
\text { construction should be assumed, with limited in-situ testing of the most critical elements }\end{array}$ & $F_{\text {RZ1 }}$ & FP $_{\text {RZ2 }}$ \\
\hline $\mathbf{K L 2}$ & $\begin{array}{l}\text { Normal knowledge - The data on mechanical properties of construction materials are } \\
\text { available from extended in-situ testing or from original design specifications. } \\
\text { In this case, limited in-situ testing should be made. }\end{array}$ & $F_{\text {RZ3 }}$ & 1.35 \\
\hline $\mathbf{K L 3}$ & $\begin{array}{l}\text { Full knowledge - The data on mechanical properties of construction materials are } \\
\text { available from comprehensive in-situ testing or from original test reports. }\end{array}$ & 1,00 \\
\hline
\end{tabular}




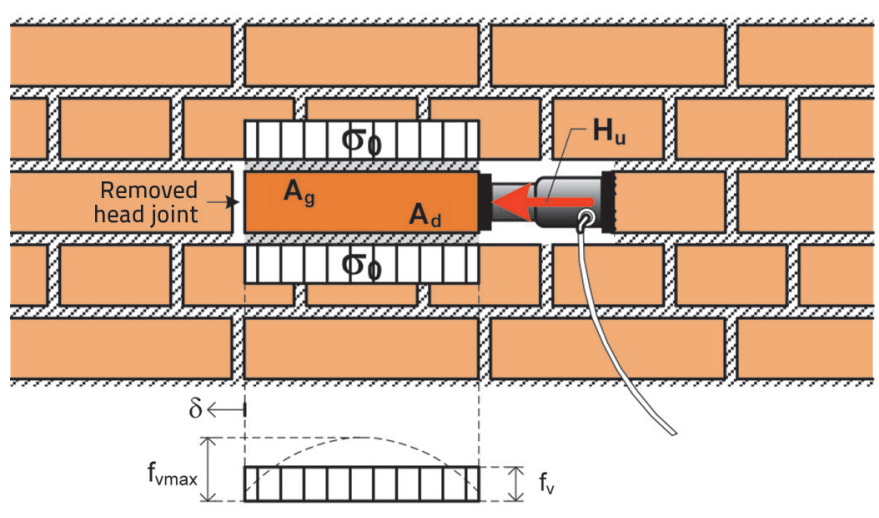

Figure 1. Testing masonry shear strength

After removing the plaster, a longitudinally oriented brick for the bed joint shear strength $\left(\mathrm{f}_{\mathrm{v}}\right)$ test has to be selected. Before the test, head joint must be removed on one side of the selected brick and on the other side there should be enough space to install the horizontally oriented hydraulic jack [5].This is usually done by removing the neighbouring brick. The masonry shear strength is determined based on the registered maximum horizontal force $H_{u}$ applied on the brick at the moment of shear failure and the corresponding top and bottom areas $\left(A_{g}+A_{d}\right)$ on which the shear is transferred. It is estimated that the contribution of mortar is small at the vertical joint behind the brick that is tested, and this contribution is therefore neglected (this back joint is often not filled with mortar and is not subjected to a higher vertical stress). The method for testing masonry shear strength is presented in Figure 1.

$f_{v}=\frac{H_{u}}{A_{g}+A_{d}}$

The test conducted, as shown in Figure 1, involves determining shear strength $f_{v}$ with the contribution of normal compressive stress $\sigma_{0}$. That is why it is necessary to accurately determine the test position, which enables the calculation of vertical load $G_{0}$ and the corresponding stress $\sigma_{0^{\circ}}$. Thus, in addition to the plan view position, it is also necessary to determine the distance $h$ of the test location from the top edge of the floor structure. The masonry shear strength $f_{v}$ depends on the shear strength without the normal compressive stress $f_{v 0}$ and the product of the normal compressive stress $\sigma_{o}$ and the coefficient of friction $\mu$.

$f_{v}=f_{v 0}+\mu \cdot \sigma_{0}$

If the objective is to estimate the shear strength without the compressive stress $f_{v 0^{\prime}}$ then the coefficient of friction $\mu$ must be estimated based on the data from the literature, e.g., according to [4], the coefficient of friction amounts to 0.4 while, according to [5], it may vary from 0.3 to 1.6 . The compressive stress value

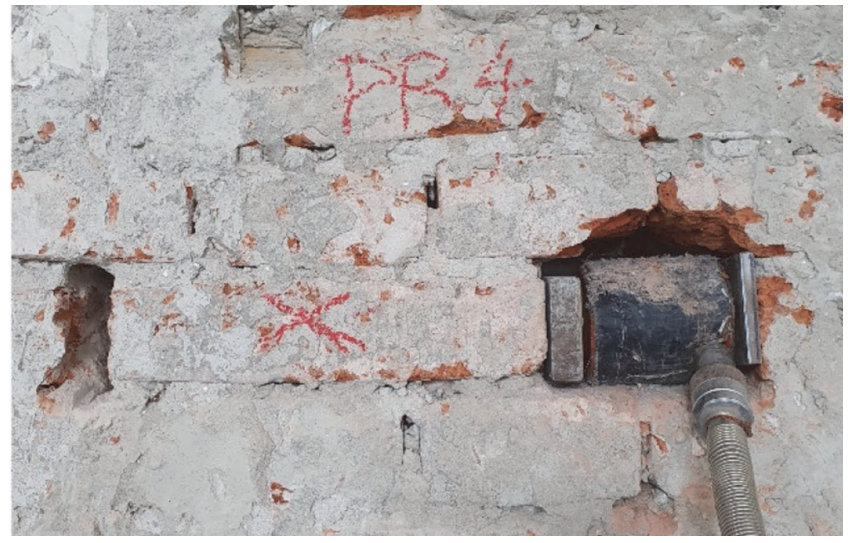

$\sigma_{0}$ can be estimated either by calculation or by adopting it from an appropriate numerical model of the structure.

$f_{v 0}=f_{v}-\mu \cdot \sigma_{0}$

The shear strength value without the compressive stress $f_{v 0}$ can also be determined based on testing involving the use of a flat jack. This method implies checking compressive stress in the masonry wall during the shear test and, at that, the coefficient of friction is also determined, Figure 2. A more detailed description of this method is given in Section 5.4.

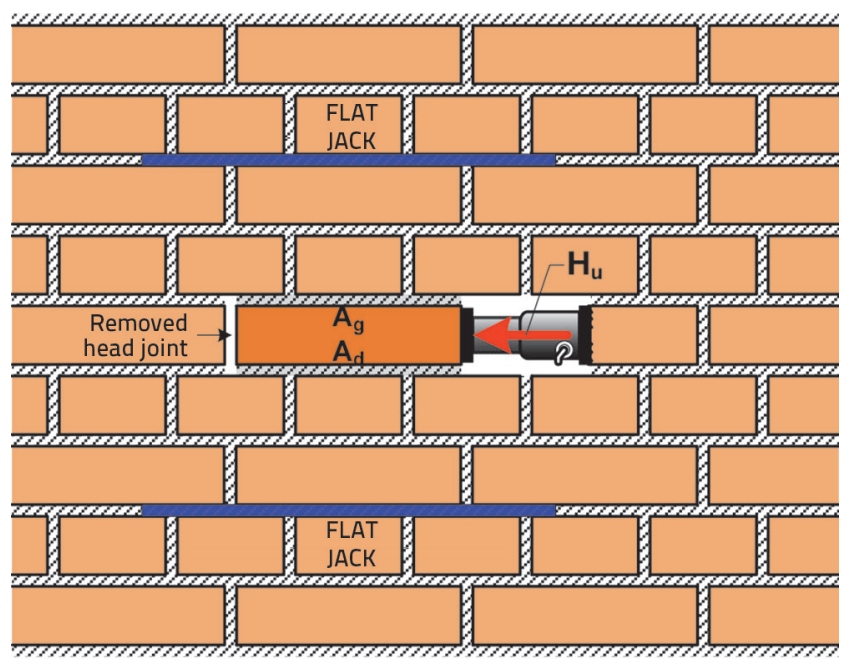

Figure 2. Testing masonry shear strength using flat jacks for normal compressive stress determination

\subsection{Masonry shear strength test results}

Masonry shear strength test results for solid brick walls, without control of normal compressive stress, obtained by testing in the city of Zagreb area, are shown in Table 3. The testing involved 20 masonry buildings and was conducted by the Structural Testing Laboratory of the Faculty of Civil Engineering - University of Zagreb. 
Table 3. Masonry shear strength test results $f_{v}$

\begin{tabular}{|c|c|c|c|c|}
\hline No. & $\begin{array}{l}\text { Building } \\
\text { Number of floors (year of construction) }\end{array}$ & $\begin{array}{l}\text { Number of } \\
\text { measurement } \\
\text { locations }\end{array}$ & $\begin{array}{l}\text { Average } \\
\text { value } \\
\text { [MPa] }\end{array}$ & $\begin{array}{l}\text { Standard } \\
\text { deviation } \\
\text { [MPa] }\end{array}$ \\
\hline 1. & $\begin{array}{l}\text { Office-residential building, Ulica Ivana Dežmana 9, Zagreb, } \\
\text { basement + ground floor + } 3 \text { floors + attic (1929) }\end{array}$ & 8 & 0.291 & 0.098 \\
\hline 2. & PAROMLIN, Zagreb, Transmission building, ground floor + 5 floors (1907.) & 5 & 0.544 & 0.112 \\
\hline 3. & PAROMLIN, Zagreb, Flour storage building, ground floor + 5 floors, (1907.) & 10 & 0.626 & 0.207 \\
\hline 4. & $\begin{array}{l}\text { St. Vincent Church and monastery, Frankopanska } 15 \text { i 17, Zagreb, } \\
\text { basement + ground floor + } 2 \text { floors + attic (1845.) }\end{array}$ & 6 & 0.572 & 0.146 \\
\hline 5. & $\begin{array}{l}\text { PALMOTIĆEVA 64a, Zagreb, } \\
\text { basement + ground floor + } 3 \text { floors + attic, (1920.) }\end{array}$ & 7 & 0.422 & 0.135 \\
\hline 6. & ĐORĐIĆEVA 8, Zagreb, basement + ground floor + 3 floors + attic, (1911.) & 4 & 0.403 & 0.048 \\
\hline 7. & GAJDEKOVA 18, Zagreb, basement + ground floor + 2 floors + attic, (1935.) & 3 & 0.404 & 0.044 \\
\hline 8. & $\begin{array}{l}\text { VINKOVIĆEVA 27, Zagreb, } \\
\text { basement + ground floor + } 3 \text { floors + attic, (1932.) }\end{array}$ & 3 & 0.287 & 0.067 \\
\hline 9. & $\begin{array}{l}\text { JURIŠIĆEVA 5, Zagreb } \\
\text { basement + ground floor + } 3 \text { floors + attic, (building permit issued in 1896.) }\end{array}$ & 3 & 0.645 & 0.115 \\
\hline 10. & $\begin{array}{l}\text { UNIVERSITY OF ZAGREB, Trg RH 14, Zagreb, } \\
\text { basement + ground floor + } 2 \text { floors + attic, (1859.) }\end{array}$ & 5 & 0.545 & 0.175 \\
\hline 11. & $\begin{array}{l}\text { CROATIA INSURANCE., Trg bana J. Jelačića } 12 \text { and 12/1, BUILDINGS } 2 \text { and } 3 \text {, } \\
\text { Zagreb, } \\
\text { basement + ground floor + } 3 \text { floors + attic, (1881.) }\end{array}$ & 3 & 0.659 & 0.155 \\
\hline 12. & $\begin{array}{l}\text { CROATIA INSURANCE, Praška 5, BUILDING 4, Zagreb, } \\
\text { basement + ground floor + } 3 \text { floors + attic, (1926.) }\end{array}$ & 3 & 0.678 & 0.205 \\
\hline 13. & $\begin{array}{l}\text { BAKAČEVA 3, Zagreb, } \\
\text { basement + ground floor + } 3 \text { floors + attic, (1912.-1913.) }\end{array}$ & 9 & 0.601 & 0.199 \\
\hline 14. & $\begin{array}{l}\text { FRANCK - MALT HOUSE, Vodovodna 20, Zagreb, } \\
\text { ground floor + } 3 \text { floors, (early 20th century) }\end{array}$ & 8 & 0.630 & 0.238 \\
\hline 15. & $\begin{array}{l}\text { KUNDEK HOUSE, Kundekova ulica 2, Ivanić Grad, } \\
\text { basement + ground floor + } 1 \text { floor + attic, (late 19th century) }\end{array}$ & 6 & 0.532 & 0.087 \\
\hline 16. & $\begin{array}{l}\text { METALČEVA ULICA 15, back building B, Zagreb, } \\
\text { ground floor + } 1 \text { floor + attic, (1939.) }\end{array}$ & 4 & 0.517 & 0.041 \\
\hline 17. & $\begin{array}{l}\text { FORMER TOBACCO FACTORY ZAGREB (TDZ), Jagićeva bb, Zagreb, } \\
\text { ground floor + } 2 \text { floors + attic, (1882.) }\end{array}$ & 7 & 0.474 & 0.087 \\
\hline 18. & $\begin{array}{l}\text { MINISTRY OF FOREIGN AND EUROPEAN AFFAIRS (MVEP), Trg N. Š. Zrinjskog } \\
\text { 7-8, Zagreb, basement + ground floor + } 3 \text { floors + attic, (1903.) }\end{array}$ & 16 & 0.637 & 0.227 \\
\hline 19. & $\begin{array}{l}\text { HOTEL PALACE, Trg Josipa Jurja Strossmayera 10, Zagreb, } \\
\text { basement + ground floor + } 4 \text { floors + attic, (1889.) }\end{array}$ & 23 & 0.593 & 0.155 \\
\hline 20. & $\begin{array}{l}\text { MASARYKOVA 10, Zagreb, } \\
\text { basement + ground floor + mezzanine + } 4 \text { floors + attic (1925.) }\end{array}$ & 16 & 0.460 & 0.081 \\
\hline
\end{tabular}



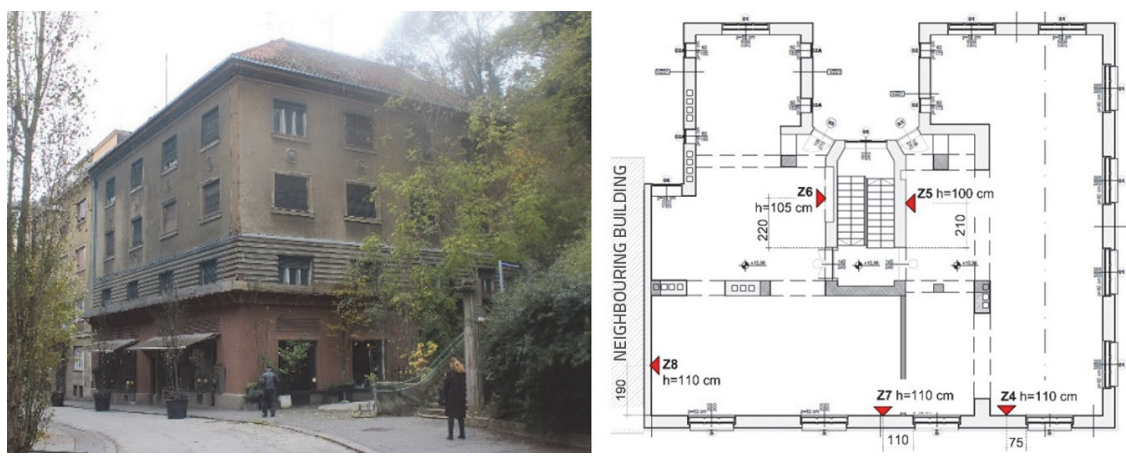

Figure 3. Office-residential building, Ulica Ivana Dežmana 9 in Zagreb (left) and $3^{\text {rd }}$ floor plan with locations in which masonry shear strength was tested (right)
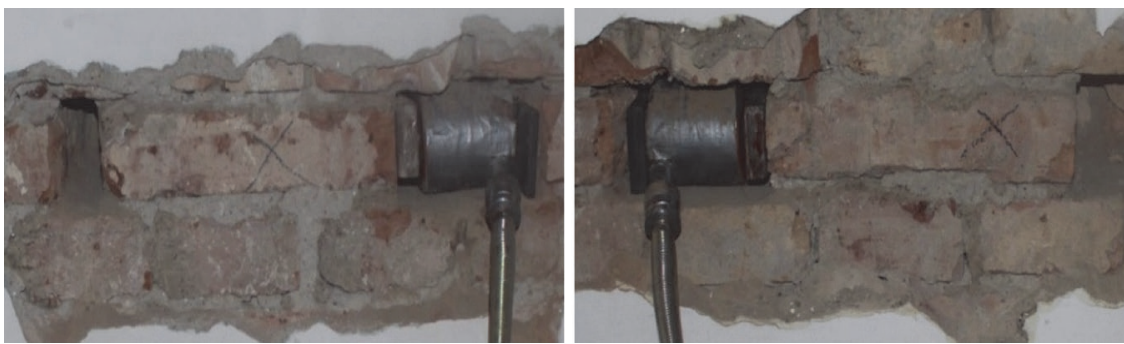

Figure 4. Office-residential building, Ulica Ivana Dežmana 9 in Zagreb, masonry shear strength testing at locations $\mathrm{Z4}$ and $\mathrm{Z6}$
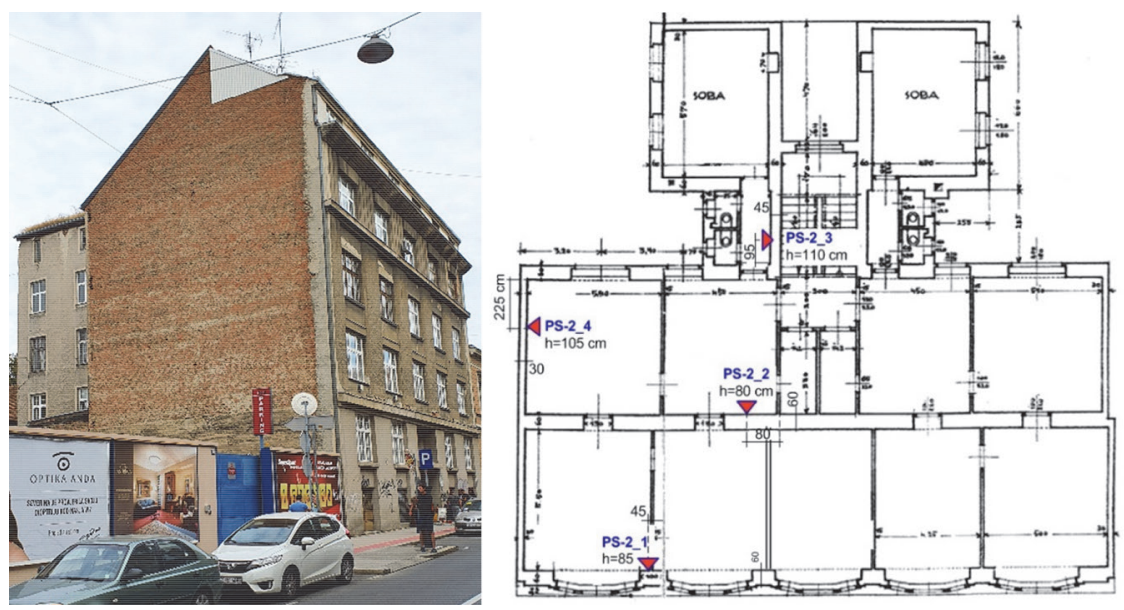

Figure 5. Residential building, Palmotićeva ulica 64a in Zagreb (left) and $2^{\text {nd }}$ floor plan with locations in which masonry shear strength was tested (right)
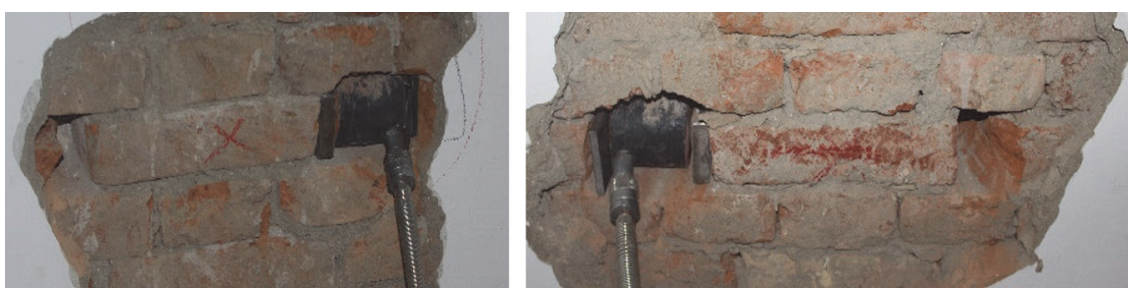

Figure 6. Residential building, Palmotićeva ulica 64a in Zagreb, masonry shear strength testing at locations PS-1-1 and PS-2-1
Average masonry shear strength values for all the buildings are shown in Figure 9. Figures 10.a and 10.b show masonry shear strength test results, presented by individual floors, for Ministry of Foreign and European Affairs (MVEP) building and Hotel Palace building in Zagreb where testing was conducted after the earthquake.

Test results for Hotel Palace (Figure 10.b) show that the masonry shear strength reduces toward top floors due to smaller self-weight load, i.e., due to smaller vertical stress at the point of testing. However, the testing has shown that this is not always the case due to the considerable test results dispersion. Test results for the MVEP building (Figure 10.a) are given as an example.

\section{In situ masonry tensile strength}

The masonry tensile strength can be determined by destructive procedure on the building (in situ). First, an appropriate location with the existing openings (doors and windows) is identified in the existing wall, or alternately two vertical openings are carefully cut out near the door opening, leaving approximately I = $80 \mathrm{~cm}$ of an undisturbed wall that keeps transferring the vertical load [6]. Figure 11 presents how the wall is subjected to load in case an appropriate location is found next to an existing door and window.

A horizontal load is applied by a hydraulic jack at half height in several loading and unloading steps by gradually increasing the load. Tensile failure occurs in the form of inclined cracks above and under the point of application of horizontal load. The compressive stress in the vertical direction has to be calculated from the load imposed on the wall and floors above the testing location. These tests are usually conducted on the lower floors of the building or on the ground floor. The testing itself is relatively complex as it presents several challenges. First, it is difficult to find an appropriate location for such testing, especially if occupants are using the space within the building. Also, it is complicated to cut out carefully two 

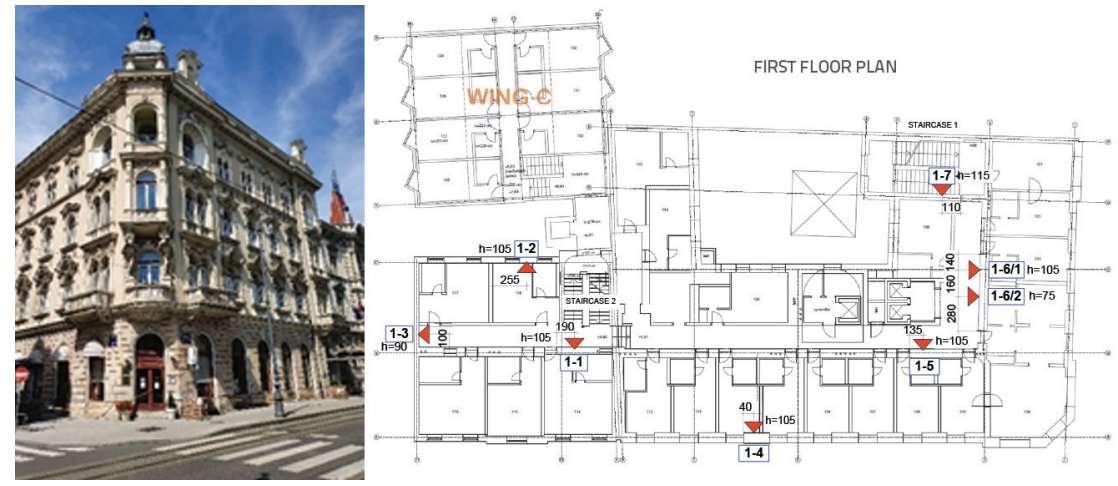

Figure 7. Hotel Palace in Zagreb (left) and $1^{\text {st }}$ floor plan with locations in which masonry shear strength was tested (right)
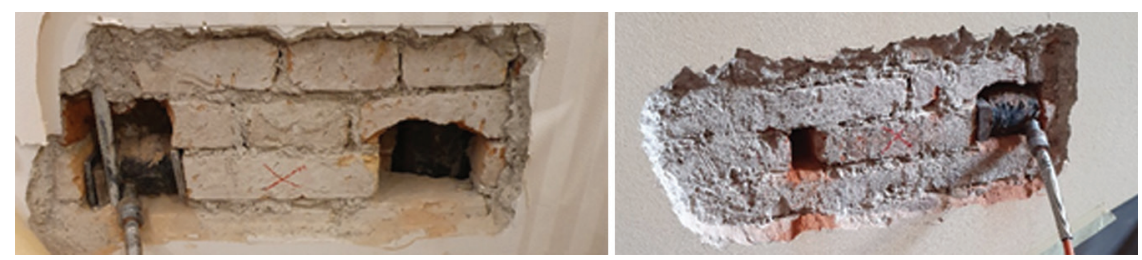

Figure 8. Hotel Palace, masonry shear strength testing at $1^{\text {st }}$ floor, at locations 1-1 and 1-7

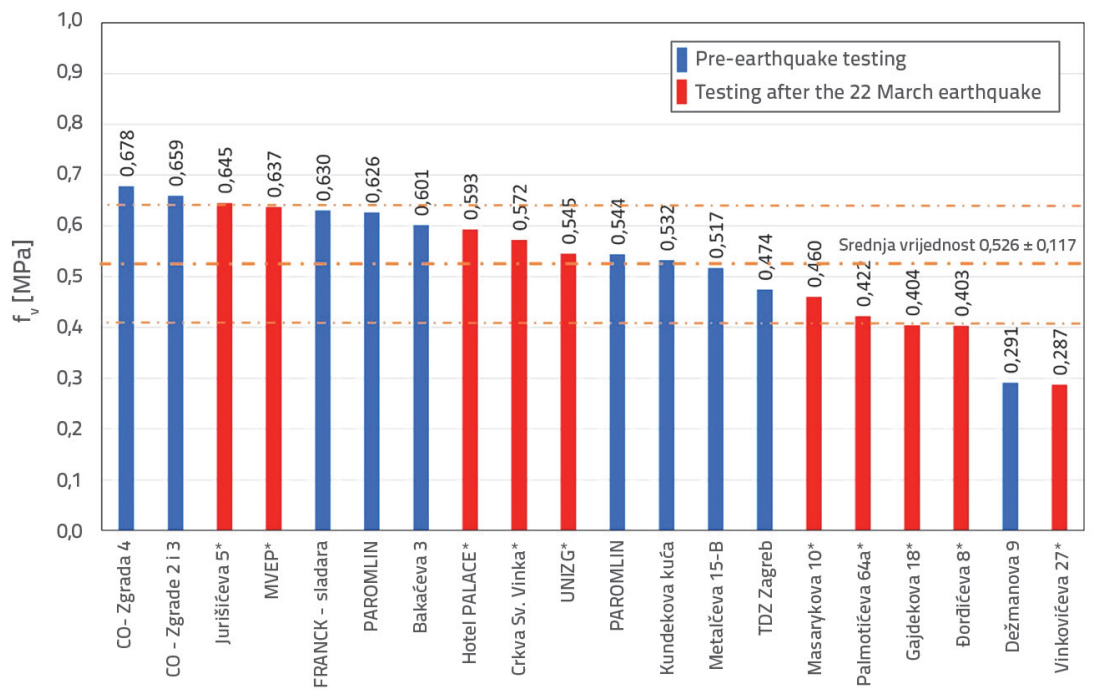

vertical openings while not deforming the part of the wall between them. Due to the redistribution of the load around these openings, it is difficult to calculate compressive stress at the testing point accurately. An average masonry shear stress is determined from the measured load $H$ at the time of occurrence of inclined cracks:

$\tau=\frac{H}{2 \cdot A}$

$A=t \cdot 1$

In the above expression, $A$ is the horizontal area of the wall that is being tested, $t$ is the wall thickness (without plaster), and / is the length of the wall between openings:

Knowing the shear stress $\tau$, and according to the calculated (estimated) compressive stress $\sigma_{o}$ in the vertical direction, the masonry tensile strength $f_{t}$ can be calculated according to $[7,8]$ :

$f_{t}=-\frac{\sigma_{0}}{2}+\sqrt{\left(\frac{\sigma_{0}}{2}\right)^{2}+(b \cdot \tau)^{2}}$

where $b$ is the highest to average shear stress ratio $(b=1,50)$. Using the tensile strength value determined by the described in situ testing, the shear strength of individual wall can be calculated according to expression (7), where $H_{u}$ is the limit shear strength of the masonry:

$H_{u}=A \cdot \frac{f_{t}}{b} \cdot \sqrt{\frac{\sigma_{0}}{f_{t}}+1}$

Figure 9. Average masonry shear strength values $f_{v}$ for all the buildings
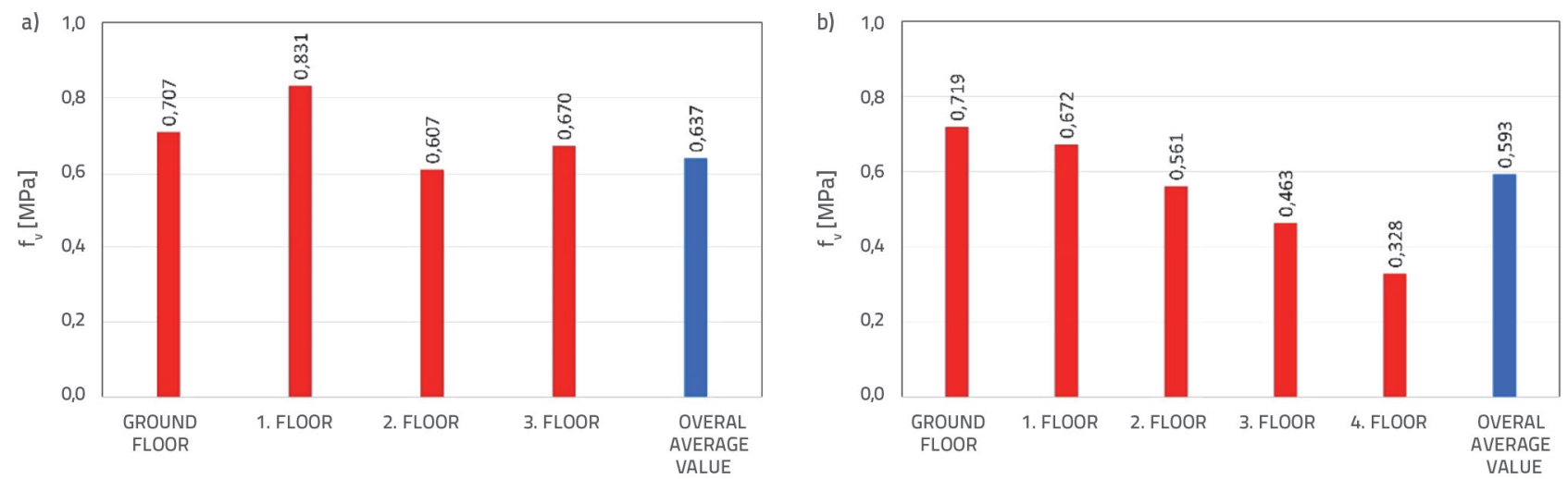

Figure 10. a) Average masonry shear strength values, presented by individual floors, for the MVEP building in Zagreb; b) Average masonry shear strength values, presented by individual floors, for the Hotel Palace building in Zagreb 


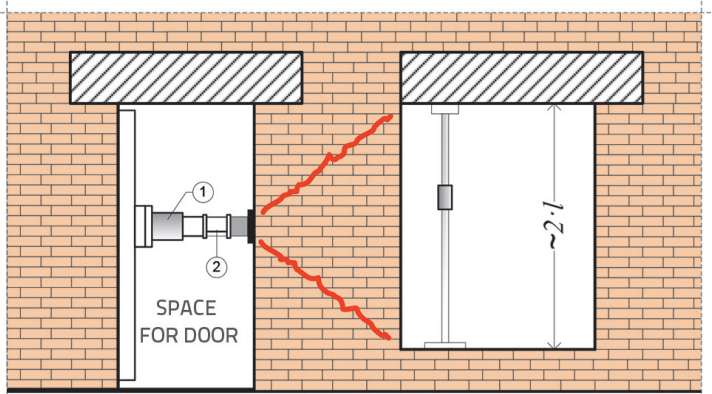

Table 4. Rate of load application during compressive strength testing of brick specimens

(1) hydraulic jack

(2) force measuring sensor (load cell)

Figure 11. Masonry subjected to in situ tensile strength testing

It is important to note that the value $f_{v}$ determined by testing presented in figures 1 and 21 must not be used instead on the tensile stress value $f_{t^{\prime}}$ as that would result in an unrealistically high value of horizontal load capacity.

\section{Brick compressive strength}

Brick compressive strength is tested according to HRN EN 772-1:2015, Methods of test for masonry units - Part 1: Determination of compressive strength [9]. According to the standard, at least six test specimens must be taken from the structure concerned. Mortar is removed from specimens, specimen surfaces are wetted, and a levelling cement mortar coat minimum of $3 \mathrm{~mm}$ in thickness is applied. Before testing, the specimens are cured by air drying for 14 days in the laboratory at the temperature of $<15^{\circ} \mathrm{C}$ and at relative moisture of $<65 \%$. The rate at which load is applied on specimens during the testing is shown in Table 4. The brick strength is obtained by dividing the maximum load at the failure by gross area, and then the result is rounded to $0.1 \mathrm{MPa}$.

\subsection{Compressive strength test results for brick specimens}

Results obtained by testing the compressive strength of brick specimens taken from masonry walls of the buildings situated in the city of Zagreb are presented in Table 5. The tests were conducted in the Structural Testing Laboratory of the Faculty of Civil Engineering - University of Zagreb. Average compressive strength values of brick specimens are shown for all buildings in Figure 14.

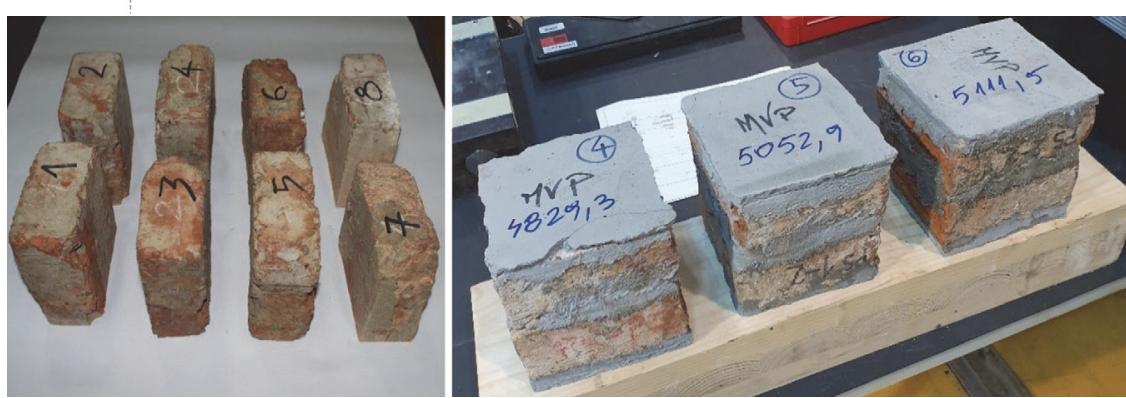

Figure 12. Brick specimens for compressive strength testing before and after the preparation for testing
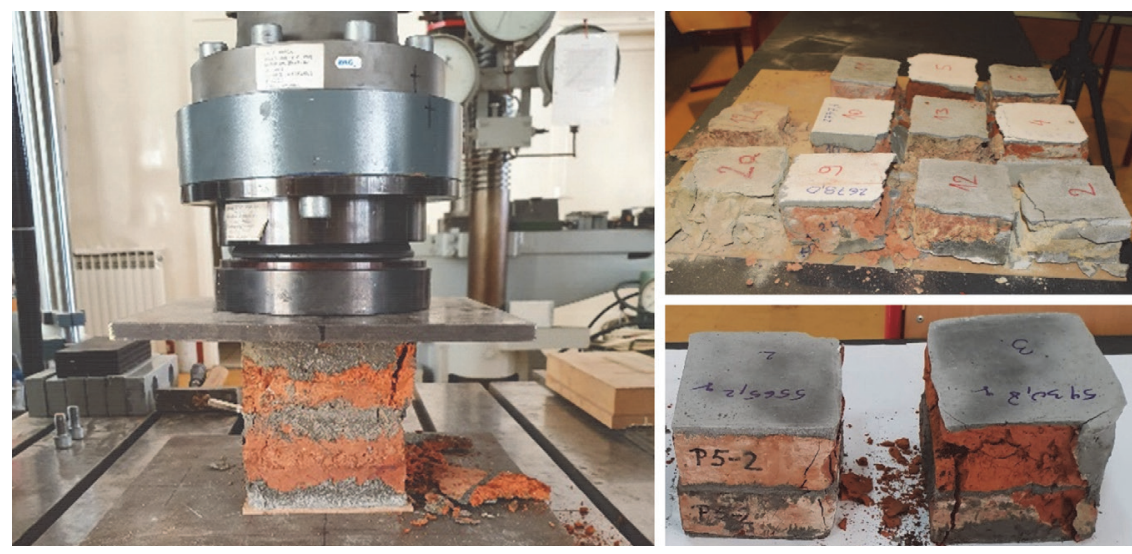

Figure 13. Testing the compressive strength of brick specimens and specimens after failure

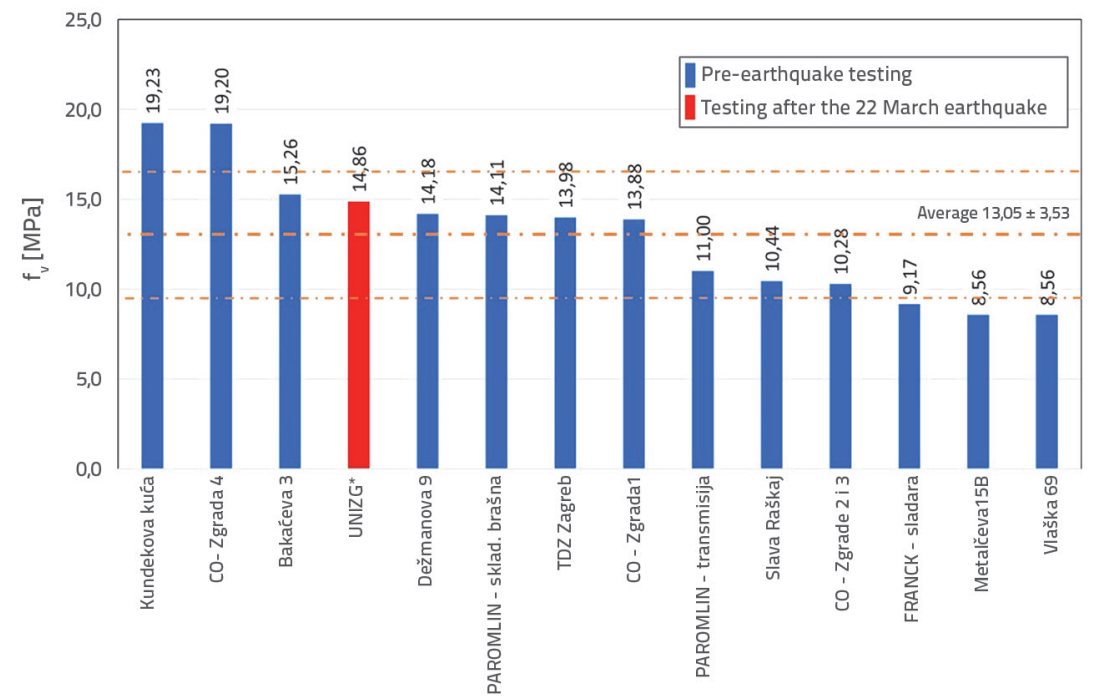

Figure 14. Average compressive strength $f_{b}$ of brick specimens for 14 buildings in the City of Zagreb 
Table 5. Results obtained by testing compressive strength of brick specimens, $f_{b}$

\begin{tabular}{|c|c|c|c|c|}
\hline No & $\begin{array}{l}\text { Building } \\
\text { Number of floors } \\
\text { (year of construction) }\end{array}$ & $\begin{array}{c}\text { Number of } \\
\text { measurement } \\
\text { locations }\end{array}$ & $\begin{array}{c}\text { Average } \\
\text { value } \\
{[\mathrm{MPa}]}\end{array}$ & $\begin{array}{c}\text { Standard } \\
\text { deviation } \\
\text { [MPa] }\end{array}$ \\
\hline 1. & $\begin{array}{l}\text { Office residential building, Ulica Ivana Dežmana 9, Zagreb, } \\
\text { basement + ground floor + } 3 \text { floors + attic, (1929.) }\end{array}$ & 8 & 14.18 & 1.73 \\
\hline 2. & PAROMLIN, Zagreb, Transmission building, ground floor + 5 floors, (1907.) & 4 & 11.00 & 1.73 \\
\hline 3. & PAROMLIN, Zagreb, Flour storage building, ground floor + 5 floors, (1907.) & 9 & 14.11 & 2.60 \\
\hline 4. & $\begin{array}{l}\text { UNIVERSITY OF ZAGREB, Trg RH 14, Zagreb, } \\
\text { basement + ground floor + } 2 \text { floors + attic, (1859.) }\end{array}$ & 3 & 14.86 & 4.65 \\
\hline 5. & $\begin{array}{l}\text { SLAVA RAŠKAJ Centre, llica 83, Zagreb, } \\
\text { basement + ground floor + } 2 \text { floors + attic, (around 1870.) }\end{array}$ & 3 & 10.44 & 1.18 \\
\hline 6. & $\begin{array}{l}\text { CROATIA OSIGURANJE, Trg bana J. Jelačića } 13 \text { i Praška ul. } 1 \text { and 3, Zagreb, } \\
\text { BUILDING 1, basement }+ \text { ground floor }+2 \text { floors }+ \text { attic (the end of } 19^{\text {th }} \text { century) }\end{array}$ & 9 & 13.88 & 4.38 \\
\hline 7. & $\begin{array}{l}\text { CROATIA OSIG., Trg bana J. Jelačića } 12 \text { and 12/1, BUILDINGS } 2 \text { and 3, Zagreb, } \\
\text { basement + ground floor + } 3 \text { floors + attic, (1881.) }\end{array}$ & 6 & 10.28 & 2.64 \\
\hline 8. & $\begin{array}{l}\text { CROATIA INSURANCE, Praška 5, BUILDING 4, Zagreb, } \\
\text { basement + ground floor + } 3 \text { floors + attic, (1926.) }\end{array}$ & 2 & 19.20 & 7.07 \\
\hline 9. & BAKAČEVA 3, Zagreb, basement + ground floor + 3 floors + attic, (1912.-1913.) & 3 & 15.26 & 1.68 \\
\hline 10. & $\begin{array}{l}\text { FRANCK - MALT HOUSE, Vodovodna 20, Zagreb, } \\
\text { ground floor + } 3 \text { floors, (early 20th century) }\end{array}$ & 2 & 9.17 & 2.12 \\
\hline 11. & VLAŠKA 69, Zagreb, ground floor + 5 storeys, (1937.) & 3 & 8.56 & 1.22 \\
\hline 12. & $\begin{array}{l}\text { KUNDEK HOUSE, Kundekova ulica 2, Ivanić Grad, } \\
\text { basement + ground floor + } 1 \text { floor + attic, (the end of 19th century. }\end{array}$ & 4 & 19.23 & 1.81 \\
\hline 13. & $\begin{array}{l}\text { METALČEVA ULICA 15, Back building B, Zagreb, } \\
\text { ground floor + } 1 \text { floor + attic, (1939.) }\end{array}$ & 4 & 8.56 & 3.48 \\
\hline 14. & $\begin{array}{l}\text { FORMER TOBACCO FACTORY ZAGREB (TDZ), Jagićeva bb, Zagreb, } \\
\text { ground floor + } 2 \text { floors + attic, (1882.) }\end{array}$ & 2 & 13.98 & 1.32 \\
\hline
\end{tabular}

\section{Test methods using flat jacks}

The use of flat jacks enables a more reliable determination of masonry mechanical properties, which have a crucial significance in the retrofit design. This primarily relates to the determination of vertical stress in the wall and the dependence between stress and strain in compression (elastic modulus). These jacks can also be used for determining compressive and shear strength values for masonry walls.

A flat jack is shaped like a bubble that is composed of two steel plates welded at the periphery. The pressure is applied to the flat jack by using a hydraulic pump equipped with appropriate input and output valves to which the jack is connected. Various forms of flat jacks are currently available and some of them are presented in Figure 15. Testing with flat jacks is described in ASTM $[5,10,11]$ and RILEM recommendations RILEM-a $[12,13]$. During the test, flat jacks are inserted in horizontal openings in the wall and stress is applied to the wall by increasing the pressure in the jack.
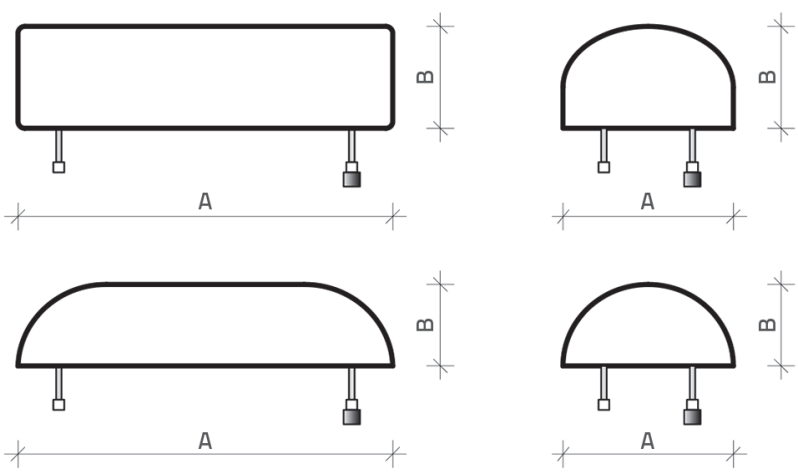

Figure 15. Various types of flat jacks

In addition to flat jacks, the equipment is formed of a hydraulic system for applying the necessary pressure, measuring devices that measure displacement/relative strain, support plates, equipment for making the openings, and accessory tools for cleaning (vacuum cleaners, brushes, etc.). The hydraulic system 

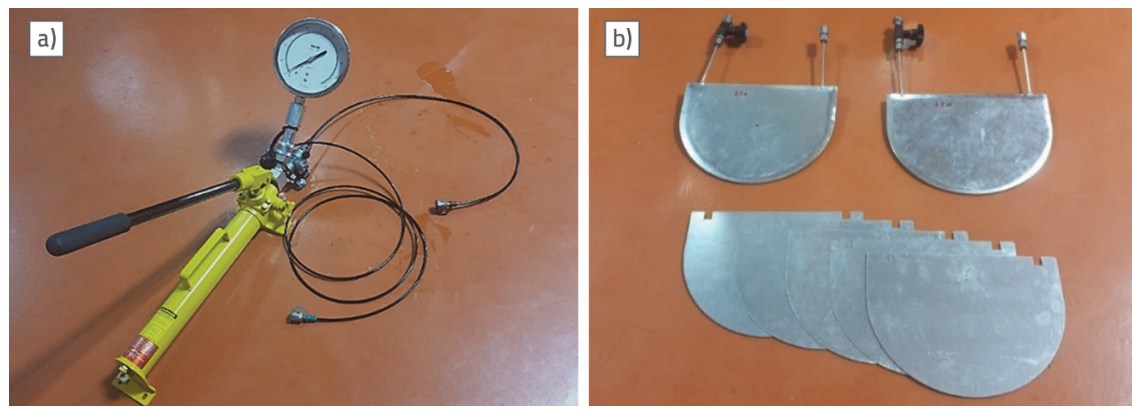

Figure 16 a) Hydraulic system for applying pressure; b) Flat jacks and steel support plates

\subsection{Flat jack calibration}

A part of the hydraulic liquid is used for deformation of the flat jack itself, which is why the pressure in the system is higher than the stress transferred to the wall by the flat jack. In order to define this influence, the flat jack must be calibrated. The coefficient $K_{m}$ must be defined to determine the relationship between the hydraulic liquid pressure and stress transferred to the wall. for applying pressure comprises a manual or electric hydraulic pump, pressure gauge, and appropriate connecting hoses (Figure 16a). The pump must maintain a constant pressure within $1 \%$ during at least five minutes in the entire working area, and the pressure gauge must be accurate to $1 \%$ in the entire measuring range. Steel support plates with dimensions corresponding to those of the flat jack (Figure 16b) are used to protect flat jacks against damage from rough surfaces in wall openings, and to fill as best as possible the opening in the wall. Mechanical strain gauges are normally used for measuring displacement/relative deformation (Figure 17a). The measurement range of these devices must be at least $5 \mathrm{~mm}$, and they must be capable of covering the gauge length as defined by flat jack dimensions (0.3 A - 0.6 A). According to ASTM standards, measurement equipment must be accurate to $\pm 0.005 \%$ of the gauge length, while RILEM recommendations require a sensitivity of no less than $0.0025 \mathrm{~mm}$. The method for preparing an opening in the wall for the flat jack is very important for the proper realisation of the testing. In fact, measurement accuracy is affected by the dimensions of the opening, and these must correspond to flat jack dimensions. When preparing the opening, the usual procedure is to remove mortar from the joints using an appropriate tool such as a drill, sabre saw, etc. If testing is conducted using flat plates of semi-circular form, it is advisable to use eccentric circular saws for making openings in walls (Figure 17b).
The calibration procedure is conducted by using the compression testing device for applying the load to the flat jack via two steel plates $50 \mathrm{~mm}$ in thickness and, at that, the axis of force action must be within $6 \mathrm{~mm}$ from the centre of the flat jack surface. The edge of the flat jack must be leveled with the edge of the top and bottom plates. Steel plates must be separated, which is obtained by inserting an appropriate spacer, the thickness of which approximately corresponds to the thickness of two metal sheets out of which the flat jack is made, multiplied by 1.33 . The calibration must be made throughout the flat jack's working range, with at least ten equal load increments. A pre-load is applied to the plates to ensure that the plates are in contact with the spacers. The pre-load corresponds to the stress of 0.07 MPa per area of the flat jack, after which the distance between plates, i.e., the position of the head of the testing machine, is no longer changed. The calibration is conducted by increasing the pressure using a hydraulic pump with $5 \%$ increments of the maximum flat jack working pressure, and this in no less than ten steps. The flat jack pressure and the load on the testing device must be registered at each step. Three calibration cycles are required. According to [10], it is necessary to define an idealised flat jack force as a product of gross area and flat jack pressure $\left(P_{p p}\right)$. When plotting the diagram, the load $P_{p p}$ is applied to the horizontal axis, while the load measured by testing device $\left(P_{15}\right)$ is applied to the vertical axis, and the coefficient $\mathrm{K}_{\mathrm{m}}$ amounts to:
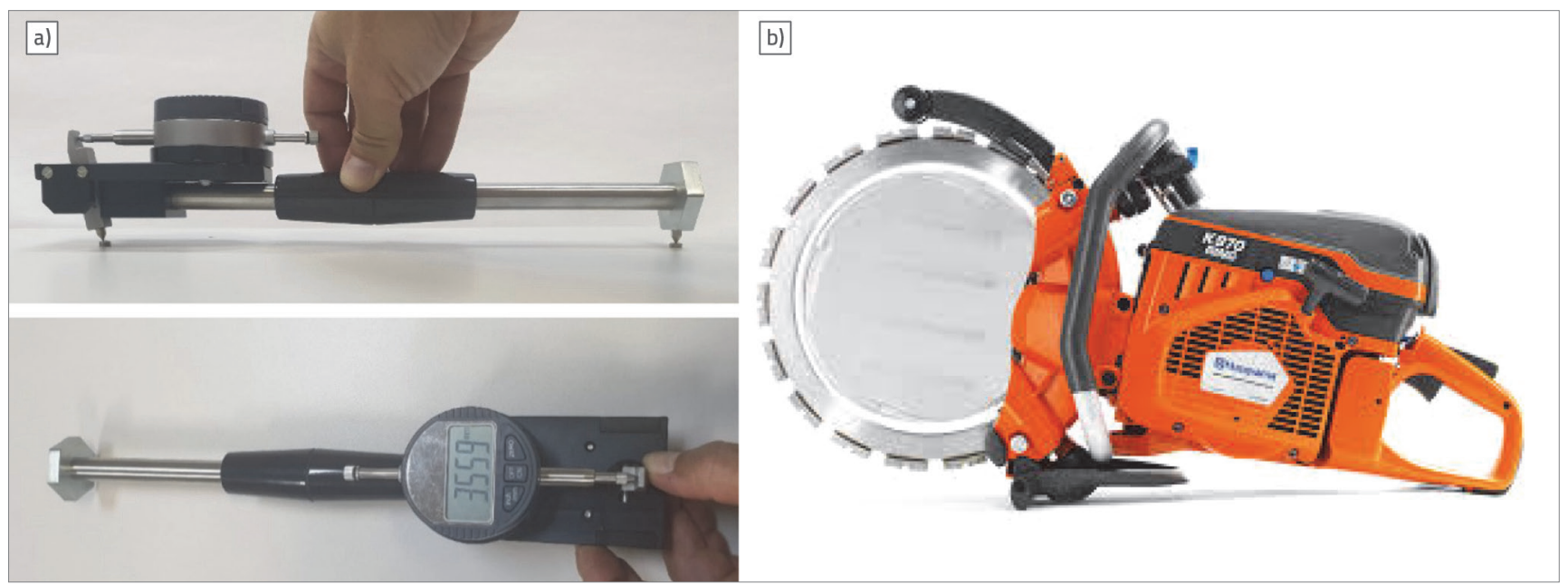

Figure 17. a) Mechanical strain gauge; b) Circular saw 

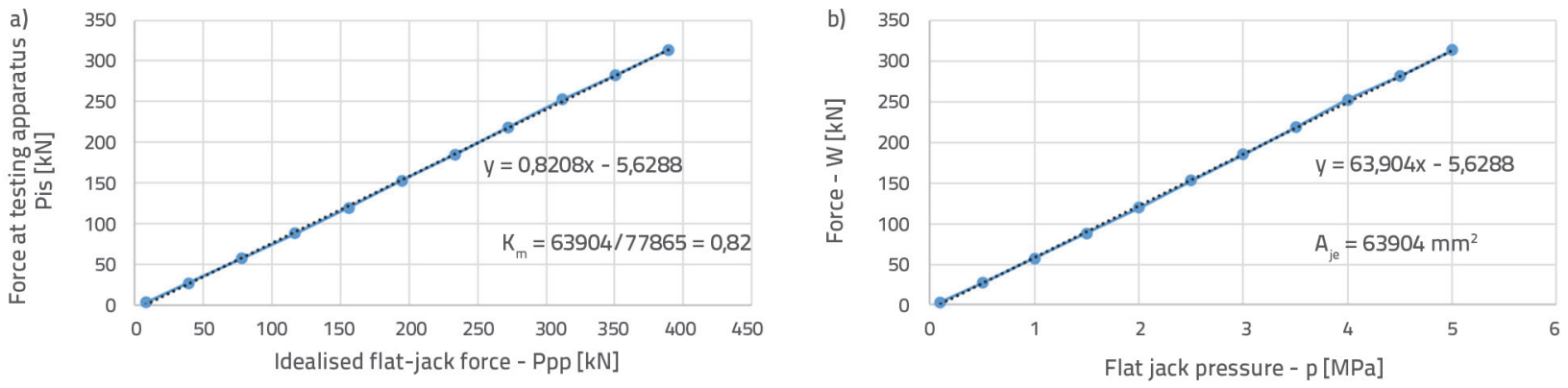

Figure 18. a) Calibration according to ASTM standards; b) Calibration according to RILEM recommendations

$K_{m}=\frac{P_{I S}}{P_{P P}}$

According to RILEM recommendations [12], the effective flat jack area $A_{j e}$ is defined as the slope of the regression line defined from the diagram in which the horizontal axis is the flat jack pressure $-p(\mathrm{MPa})$, while the vertical axis is the load at the testing device $-W(\mathrm{kN})$

$A_{j e}=\frac{W}{p}$

The calibration must be repeated after five tests or after a significant deformation of the flat jack. An example of calibration according to ASTM and RILEM is shown in Figure 18.a and 18.b.

\subsection{Determination of existing compressive stress in masonry}

The testing principle can be described as follows: the compressive stress in masonry is partly reduced by removing mortar from the bed joint, and then the stress is compensated by inserting the flat jack into the opening until the initial state of stress and strain is established, which is controlled by measuring displacement perpendicular to the opening. It should be noted that the stress determined by this testing is an average value of stress in the part of the wall near the opening, i.e. it can be assumed that the stress is representative for the entire wall only in case the wall is fully homogeneous and when the load is not eccentric.

Before the testing, plaster should be removed at the selected test position, and then the spot at which the opening (bed joint) is be made will have to be marked, which includes placing metal reference gauge points for the mechanical strain gauge. The gauge length (measurement base) must be between 0.3 and 0.6 of the size $A$ of the flat jack, and at least three pairs of such gauge points should be placed at the brick surface. The initial measurement of gauge length should be made before the preparation of the opening, i.e. before removal of mortar from the selected joint. As already mentioned, the opening can best be prepared using a circular saw, but that can only be done if semi-circular flat jacks (within $12 \mathrm{~mm}$ ) are used, and the joint must thoroughly be cleaned by removing all mortar so that the pressure can be applied directly onto the brick.

The change in gauge length is measured once flat jacks have been placed into the opening, using shims so that the flat jack would fill the opening as best as possible. The pressure is then applied in the flat jack in the amount of up to 50 percent of the pressure corresponding to the masonry's expected stress, and then the pressure is reduced to zero. During the test, the pressure is applied in 25 percent increments until the masonry's compressive stress is achieved, i.e. until the gauge length returns to the initial length (if $d=d_{0}$ then $\sigma=\sigma$ ). In the final step of this test, the deviation of the gauge length from the initial one must be within $\pm 0,013 \mathrm{~mm}$ for the mean value of all gauge points or less than $1 / 20$ of the initial reduction of the gauge length, provided that individual gauge points do not deviate by more than $0.025 \mathrm{~mm}$ or $1 / 10$ from the initial reduction of gauge length [10]. According to RILEM [12] the initial pressure must be realized in approximately eight increments that are not smaller than $0.05 \mathrm{MPa}$. At each level, the gauge length is measured three times for each gauge point. The pressure is then relieved, and the procedure is repeated to confirm the final pressure in the flat jack. After the testing, the opening is filled with mortar. Figure 19 shows the setup and basic steps of the testing procedure. According to ASTM [10], the stress in masonry $f_{m}$ is determined according to the following expression:

$f_{m}=K_{m} K_{a} p$

where $K_{m}$ is the dimensionless coefficient that depends on the geometry and stiffness of the flat jack, and is determined by calibration, $K_{a}$ is the dimensionless coefficient that is determined as the ratio of the measured area of the flat jack to the area of the slot, while $p$ is the pressure in flat jack that is needed to restore the gauge length to the initial one.

According to RILEM [12], the stress in masonry $S_{r}$ is determined according to the following expression:

$S_{r}=K_{e} p A_{\text {slot }} / A_{j e}$

where $K_{e}$ is the dimensionless coefficient that depends on the position of opening as related to joints, the relative size of flat jack and brick, and geometric properties of flat jack (for typical brick dimensions of 200-300 mm to $75-125 \mathrm{~mm}$; for the case in which flat jack is inserted into the joint and the jack dimensions are similar to brick dimensions the coefficient $\mathrm{K}_{\mathrm{e}}$ is assumed to be 0.83 , and in other cases the value cited in literature is used), $A_{\text {slot }}$ is the opening area, $A_{j e}$ is the effective area of flat 


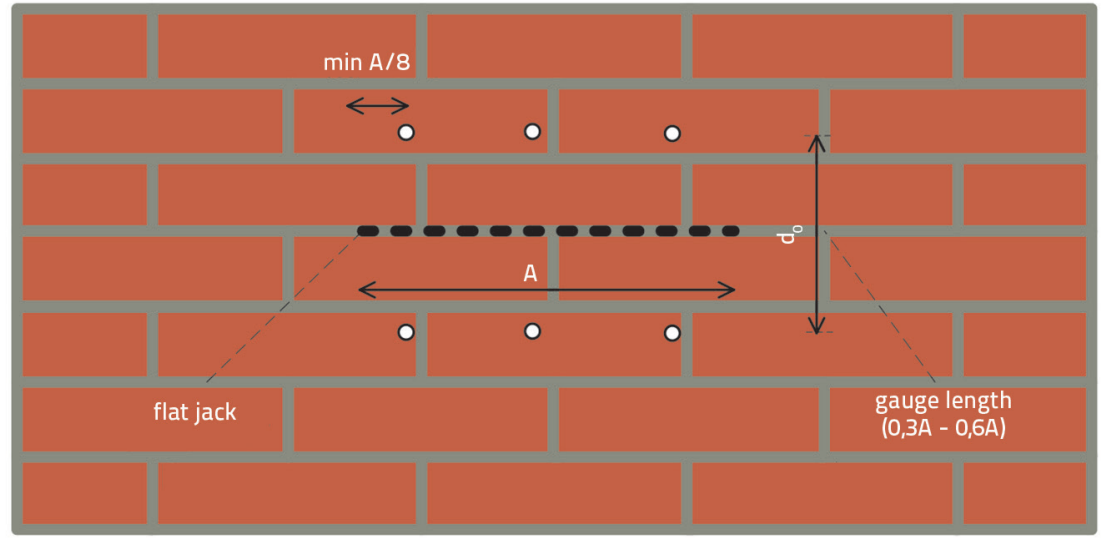

$\sigma_{0}$

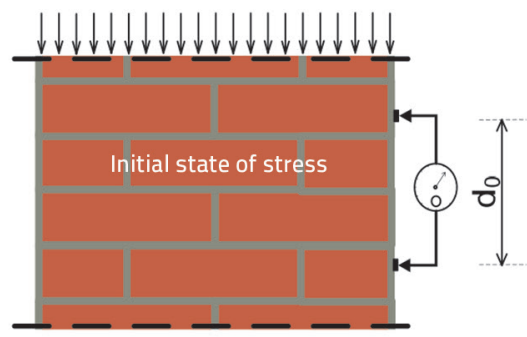

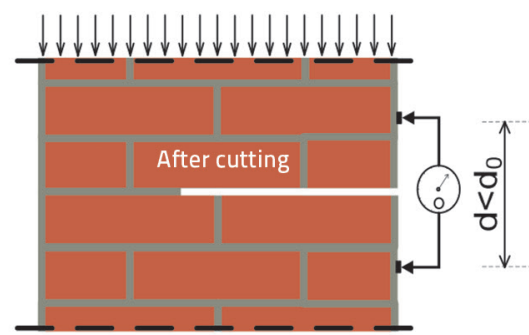

$\sigma_{0}$

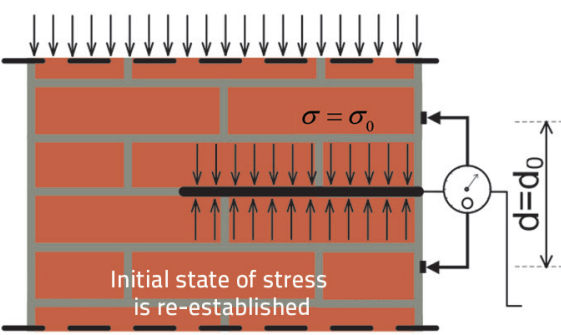

Figure 19. Procedure for determining stress in masonry

jack, and $p$ is the pressure in flat jack that is needed to bring the measurement length back to the initial one.

The testreportshould contain the following information: description of the site, environmental conditions (e.g. temperature), data about the building (type, description, etc.), year of construction, name of testing technician, date of testing, data about test zone within the building, data about the masonry, visual estimation of the building's condition, sketches, opening preparation method, the sketch of the opening and gauge points including all necessary dimensions, photographic documentation, data about the equipment and support plates, data about $K_{m^{\prime}} K_{d^{\prime}}$ pand calculation of $f_{m}$ or the data about $A_{j e} A_{\text {slot' }} K_{e}$ and calculation of $S_{r^{\prime}}$

The method's expected deviation can be up to $20 \%$, and at least three tests have to be made on similar masonry walls.

\subsection{Determining stress-strain dependence of masonry}

Two flat jacks connected to a single hydraulic pump must be used in order to determine the stress-strain dependence of masonry. Flat jacks are inserted into parallel horizontal openings in the masonry and the compressive stress is applied by locally applying pressure to the jacks. Devices for measuring strain are placed in between flat jacks, and the stress and strain values are measured simultaneously, which enables the determination of the modulus of elasticity. It should be noted that a part of the wall that is tested is still connected (the openings do not fully separate the wall volume that is tested), which constitutes a measurement uncertainty that can not be eliminated. However, regardless of this, the elastic modulus value's accuracy is still satisfactory [13].
A part of the masonry wall without significant damage or irregularities is selected before the testing. Plaster is removed from the selected part of the masonry, and spots at which the openings will be made are marked. These openings in the wall must be made in such a way that minimum damage is inflicted on the surrounding parts of the wall. The openings have to be realized in parallel, one above the other, and must be spaced no less than five bricks from each other. In case of a stone wall, no less than three stone elements should separate individual openings. In any case, the distance between openings must be greater than the size $A$ of the flat jack, but should not exceed 1.5A. To ensure an optimum accuracy of the method, the size $A$ of the flat jack must be equal to or greater than 1.5 of the brick length, if the brick is longer than $200 \mathrm{~mm}$, while it should be two times greater if the brick measures less than $200 \mathrm{~mm}$ in length.

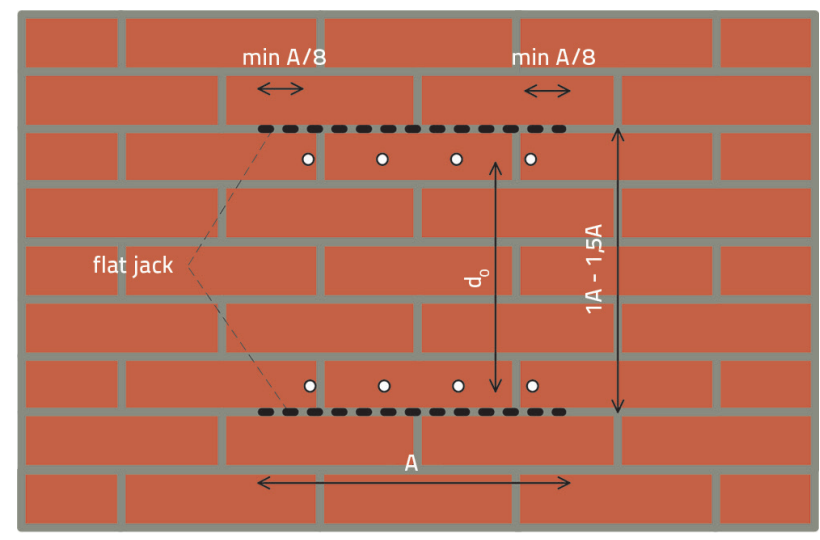

Figure 20. Procedure for determining stress-strain dependence of masonry 
LVDT sensors can be used instead of mechanical strain gauges for strain measurements, enabling continuous recording of stressstrain data. A sensor with analogous stress output and the corresponding data acquisition system must be used to obtain continuous records of hydraulic pump pressure measurements. It is recommended to perform strain measurements on at least four gauge points in the space between flat jacks, which includes determination of an average value. The measurement base must cover $75-90 \%$ of the distance between flat jacks.

As already indicated, it would be most appropriate to use eccentric circular saws for realisation of openings in the cases when semi-circular flat jacks are used.

Flat jacks are inserted into the openings using steel support plates. Before the testing, it is advisable to apply pressure amounting to approximately $50 \%$ of the masonry's compressive strength to ensure uniform and even contact between flat jacks and steel support plates, and the surface of the opening. After the initial loading, the pressure in the jack is released. The zero measurement is made prior to the test itself and then the pressure is increased in increments of approximately $10 \%$ of the expected maximum stress. In every step, the pressure is maintained for at least one minute or until it stabilizes, and then the strain values are recorded. During the testing, it is necessary to monitor an increase in pressure $d p$ as related to an increase in deformation $d e_{m}$ and, and in case this relationship decreases, the testing must be stopped to avoid significant damage to the wall. After the testing, the openings must be filled with mortar. The testing procedure is presented in Figure 20.

The stress in masonry is determined using expressions (10) and (11). The tangent elastic modulus is determined at any level of stress using the following expression:

$E_{t}=d f_{m} / d e_{m}$

where $d f_{m}$ is the increment of stress, while $d e_{m}$ is the increment of strain at the chosen stress level.

The secant elastic modulus for any level of stress is determined according to the following expression:

$E_{s}=f_{m} / e_{m}$

where $f_{m}$ is the stress at a selected level, while $e_{m}$ is the strain at a selected level.

The test report should contain the following information: the description of the site, environmental conditions (e.g. temperature), data about the building (type, description, etc.), year of construction, name of testing technician, date of testing, data about test zone within the building, data about the masonry, visual estimation of the building's condition, sketches, opening preparation method, sketch of the opening and gauge points including all necessary dimensions, photographic documentation, data about the equipment and support plates, data about $K_{m^{\prime}} K_{a^{\prime}} p$ and calculation of $f_{m}$ or the data about $A_{j e^{\prime}} A_{\text {slot' }} K_{e}$ and calculation of $S_{r^{\prime}}$ stress - strain diagram, and tangent or secant elastic modulus values.
This method can be used to determine the compressive strength of masonry in older walls characterized by small compressive strength. However, such testing can cause greater damage in the test zone and it, therefore, can not be recommended as a reliable method for the determination of compressive strength [13].

\subsection{Test method for in situ measurement of masonry shear strength with flat jacks controlling normal compressive stress}

The method used for testing in situmasonry shear strength, with normal compressive stress control using flat jacks, is described in this section. The testing is conducted as described in Section 2 , and the compressive stress is applied and checked according to the method described in Section 5.2. This method's advantage lies in the possibility of controlling vertical stress when testing masonry shear strength, which enables determination of shear strength without normal compressive stress $f_{\text {vo. }}$ The masonry shear strength $f_{v}$ depends on shear strength without normal compressive stress $f_{v o}$ and the product of normal compressive stress $\sigma_{0}$ and coefficient of friction $\mu$.

$f_{v}=f_{v 0}+\mu \cdot \sigma_{0}$

Test procedures are presented in Figure 21. Horizontal openings for flat jacks are realized in bed joints so that five rows of bricks are situated between the openings. In the central row, the brick is removed next to the brick on which testing is conducted and, on the other side of the tested brick, the mortar is removed from the head joint to free up space for horizontal displacement. The hydraulic jack and the corresponding steel plates for load transfer are inserted in the space that has been made by brick removal. After the application of compressive stress, the horizontal load is applied via hydraulic jack. The compressive stress is determined according to expressions (10) or (11) as defined in Section 5.2. When the connection between the brick and mortar fails, the brick will be displaced at the constant force that represents the maximum force for vertical compressive stress at which the testing is conducted. The same procedure will be applied for at least two additional levels of vertical compressive stress.

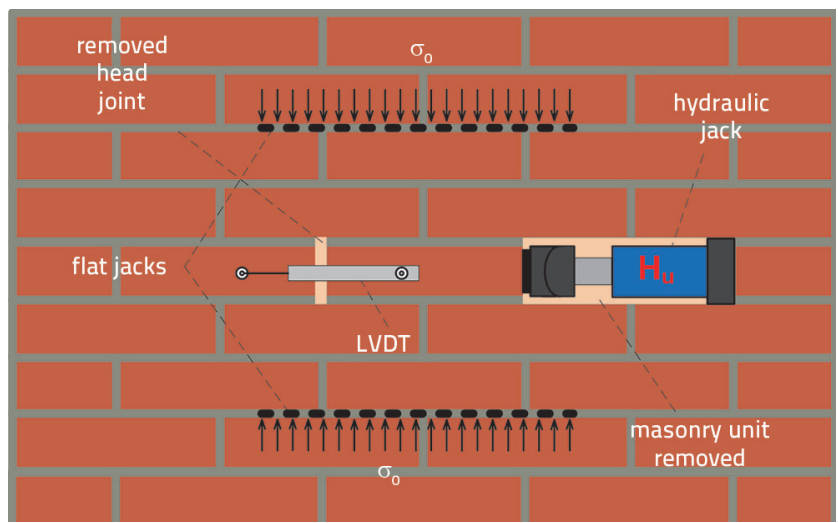

Figure 21. Procedure for determining in situ masonry shear strength, where flat jacks are used to control vertical compressive stress 
The described procedure can be used to determine the diagram showing dependence between displacement $\delta$ and masonry shear strength, as shown in Figure 22.

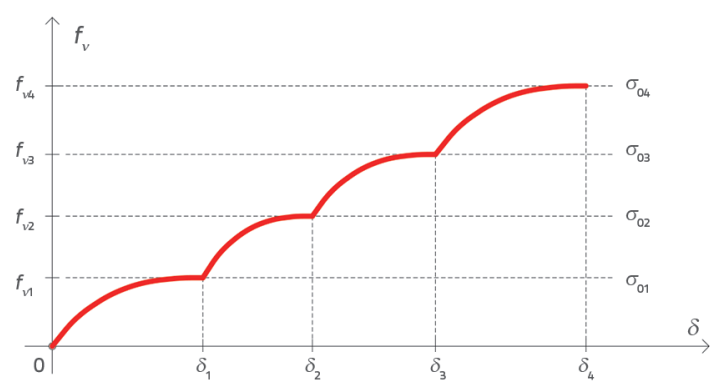

Figure 22. Diagram showing dependence between displacement $d$ and masonry shear strength $f_{v}$ [6]

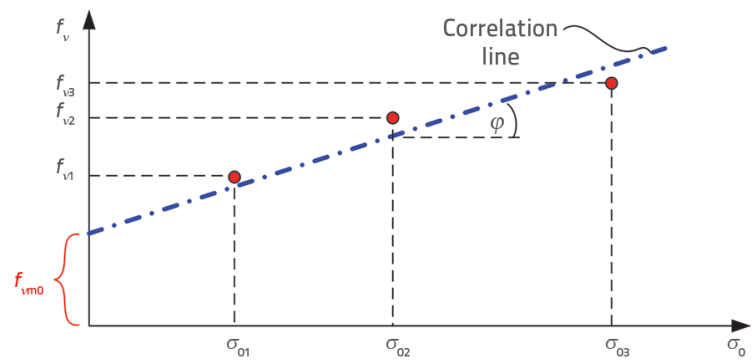

Slika 23. Compressive stress - shear strength diagram

Once the shear strength values $\left(f_{v 1^{\prime}} f_{v 2^{\prime}} f_{v 3}\right)$ have been determined, as shown above, at controlled levels of vertical compressive stress $\left(\sigma_{01}, \sigma_{02}, \sigma_{03}\right)$, three points are defined in the coordinate system where the vertical compressive stress is shown at the horizontal axis, and the shear strength at the vertical axis. It is now possible to define the correlation line (the Coulomb failure criterion), which forms with horizontal axis the angle ( $\varphi$ - the angle of internal friction), while the tangent of this angle is the coefficient of friction (Figure 23).

The shear strength without vertical compressive stress can then be defined according to expression (14), and the intercept of correlation line and the vertical axis is the mean value of shear strength without vertical compressive stress $\left(f_{v m o}\right)$ for three tests:

$f_{v m 0}=f_{v i}-\mu \cdot \sigma_{0 i}=f_{v i}-\operatorname{tg} \varphi \cdot \sigma_{0 i}$

Experimental determination of shear strength and coefficient of friction can be affected by local irregularities and inhomogeneities of the masonry wall, by head joints, and by inaccuracy in the determination of vertical compressive stress [14].

Because of the removal of the neighbouring brick, the compressive stress that acts on the tested brick is higher than the stress that is applied via flat jacks, so it has to be corrected. The correction factor is unique and depends on the test setup, on the flat jack's size, and tested bricks. Thus, the information specifying various configurations is not available in the literature. For the test setup presented in Figure 24, the compressive stress of the tested brick can be as much as 1.7 times higher than the one applied via flat jacks [14].

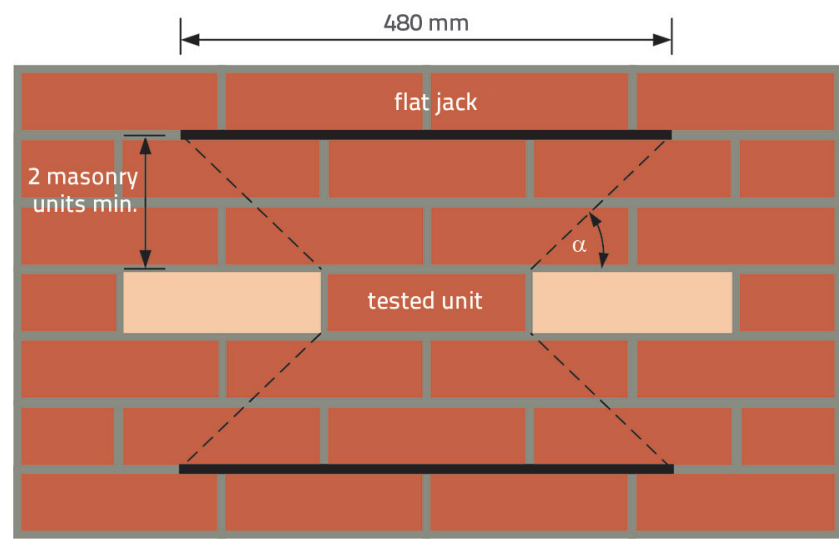

Figure 24. Test configuration in which the correction factor amounts to 1.7
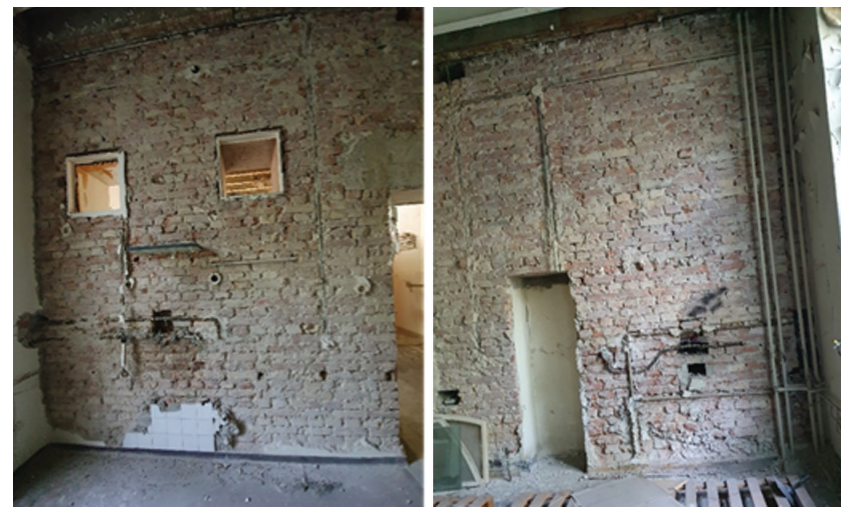

Figure 25. Typical masonry walls with openings and installations

In addition to the above-mentioned difficulties, problems can occur when trying to find an adequate location fur such testing in buildings, especially if the buildings are in use during the testing. In this respect, it is necessary to find an adequate wall surface, which is very difficult as walls normally have many openings, installations, closed (walled up) openings, and chimneys, and in many instances, full brick masonry is encountered, which prevents this testing (Figure 25). Furthermore, the openings for the insertion of flat jacks are cut with diamond grinding plates using water and so the wall becomes saturated with water. Thus, it is necessary to wait for the wall to dry up before proceeding to the testing. As a result, this testing lasts a long time and is quite expensive.

\section{Conclusion}

Despite the above-mentioned difficulties, the in situ masonry shear strength testing results, with normal compressive stress control via flat jacks, provide valuable data about friction coefficients and compressive stress in masonry walls. In the absence of such testing, friction coefficients are taken from literature or standards, while compressive stress can be assumed via a calculation model. Before the intensification of 
activities for the renewal of earthquake-damaged buildings, it would be highly significant to conduct a representative number of such tests on typical buildings, and so an adequate funding should be secured for this purpose. The funds invested in this test would pay off through expected savings in renovation costs, as designers would consider real failure criteria, and complex and expensive tests would not have to be conducted on every building. The simple shear test results also provide the designer with a highly valuable information about the masonry wall condition. If the following is inserted in expression (15):

- average shear strength value obtained by simple shear tests shown in Section 2.1 reduced for standard deviation, $f_{v m}=0,526-0,117=0,409 \mathrm{MPa}$

- coefficient of friction $\mu=0,6$, which exceeds by 1.5 times the value given in standard [4]

- compressive stress $\sigma_{0}=0,4 \mathrm{MPa}$,

- for the shear strength value without normal compressive stress, we obtain obtain 0.169 MPa $\left(f_{v m 0}=f_{v m}-\operatorname{tg} \varphi \cdot \sigma_{0}=\right.$ $0,409-0,6 \cdot 0,4=0,169 \mathrm{MPa})$
Even with high values of $\mu$ and $\sigma_{0}$, the shear strength without vertical normal compressive stress is higher than the one specified in standards for the case when no testing is made. The calculation presented in equation (16) would be much more reliable if relevant data, obtained on a representative sample, existed about friction coefficients and compressive stress. In such a case, the results obtained by a simple shear test could be used with higher confidence.

Here it is important to emphasize once again that calculation of masonry shear strength (even with the values established in situ) will not provide a reference value of resistance to be compared with calculated action $(E d<R d)$. It is important also to check the other two ways of reaching masonry wall failure (failure by reaching tensile strength of wall with the occurrence of an inclined crack, and failure by crushing the compressive zone of the wall exposed to vertical force, horizontal force and bending moment).

\section{REFERENCES}

[1] Šavor Novak, M., Uroš M., Atalić J., Herak M., Demšić M., Baniček, M., Lazarević, D., Bijelić, N., Crnogorac, M., Todorić, M.: Zagreb earthquake of 22 March 2020 - preliminary report on seismologic aspects and damage to buildings, Gradevinar, 72 (2020) 10, pp. 843-867, https://doi.org/10.14256/JCE.2966.2020

[2] HRN EN 1996-1-1: Eurocode 6: Design of masonry structures -Part 1-1: General rules for reinforced and unreinforced masonry structures, HZN, Zagreb, 2012

[3] HRN EN 1998-1:2011, Eurocode 8: Design of structures for earthquake resistance -- Part 1: General rules, seismic actions and rules for buildings, HZN, Zagreb, 2011.

[4] HRN EN 1998-3:2011 + NA:2011, Eurocode 8: Design of structures for earthquake resistance -- Part 3: Assessment and retrofitting of buildings, HZN, Zagreb, 2011.

[5] ASTM C1531-16... Standard Test Methods for In Situ Measurement of Masonry Mortar Joint Shear Strength Index, ASTM International, 2016.

[6] Sorić, Z:: Zidane konstrukcije, Zagreb, 2016.

[7] Turnšek, V., Čačovič, F.: Some Experimental Results on the Strength of Brick Masonry Walls, Proceedings of the 2nd International Brick Masonry Conference, Stoke-on-Trent, pp. 149-156, 1971.
[8] Kišiček T., Stepinac M., Renić T., Hafner I., Lulié L.: Strengthening of masonry walls with FRP or TRM, Gradevinar, 72 (2020) 10, pp. 937-953, https://doi.org/10.14256/JCE.2983.2020

[9] HRN EN 772-1:2015: Methods of test for masonry units -- Part 1: Determination of compressive strength, HZN, Zagreb, 2015.

[10] ASTM C1196-14a: Standard Test Method for In Situ Compressive Stress Within Solid Unit Masonry Estimated Using Flatjack Measurements, ASTM International, 2014.

[11] ASTM C1197-14a: Standard Test Method for In Situ Measurement of Masonry Deformability Properties Using the Flatjack Method, ASTM International, 2014.

[12] RILEM TC 177-MDT: Test method recommendations of RILEM TC 177-MDT 'Masonry durability and on-site testing' - D.4: In-situ stress tests based on the flat jack, Materials and Structures, 37 (271), pp. 491-496, 2004.

[13] RILEM TC 177-MDT: Test method recommendations of RILEM TC 177-MDT 'Masonry durability and on-site testing' - D.5: In-situ stress - strain behaviour tests based on the flat jack, Materials and Structures, 37 (271), pp. 497-501, 2004.

[14] RILEM TC 127-MS: Recommendations of RILEM TC 127-MS: Tests for masonry materials and structures, Materials and Structures, 29 (192), pp. 459-475, 1996. 